GEOGRAFICKÝ ČASOPIS / GEOGRAPHICAL JOURNAL 73 (2021) 3, 239-263

DOI: https://doi.org/10.31577/geogrcas.2021.73.3.13

\title{
GEOGRAFICKÁ GRAMOTNOSŤ MLADÝCH LUDÍ NA SLOVENSKU
}

\author{
Štefan Karolčík*, Dominika Vavrincová*, Elena Čipková* \\ * Univerzita Komenského v Bratislave, Prírodovedecká fakulta, Katedra didaktiky prírodných vied, \\ psychológie a pedagogiky, Ilkovičova 6,84215 Bratislava 4, \\ stefan.karolcik@uniba.sk,domca.vavrincova@gmail.com,elena.cipkova@uniba.sk
}

\begin{abstract}
Geo-literacy of young people in Slovakia
Geo-literacy as the final goal of geographical education is the ability of an individual to use geographical understanding and geographical reasoning to make important decisions with a far-reaching effect. The goal of the paper is to present the results of our research aimed at determining the achieved level of geographic literacy in young people aged from 18 to 24 in Slovakia. Our research activities also included analyzes of respondents' attitudes and opinions on geography and their perception of its importance in today's world, as well as findings on the extent of geographical knowledge of young Slovaks related to their ability to orient themselves in current events at home and abroad. Generally, the research results showed a very good level of geographic literacy. The average number of points of the participating respondents was 34.2 (SD $=7.44$ ), which represents the percentage score of 71.2.
\end{abstract}

Key words: literacy, geographic literacy, geography education, Slovakia

\section{ÚVOD}

V diskusiách o význame, ciel’och a úlohách geografického vzdelávania sa často pracuje s pojmom gramotnost' (angl. literacy). V minulosti bol tento pojem spájaný najmä so schopnostou jedinca písat', čítat' a počítat'. V súčasnosti je gramotnost' chápaná omnoho širšie a významovo komplexnejšie, pričom sa v mnohých definíciách zdôrazňuje najmä aplikačný, v reálnom živote uplatnitel'ný charakter gramotnosti, ktorý okrem iného zahíňa schopnost' informáciám prezentovaným v rôznych grafických podobách rozumiet', vediet' ich spracovat' a v každodennom živote používat' (Průcha et al. 2001, Gavora 2006 a Průcha 2009).

V oblasti vzdelávania takto široko a komplexne chápaná gramotnost' spôsobuje rad problémov a významne st’ažuje vol'bu vhodných učebných postupov a stratégií umožňujúcich jej rozvoj. Viacerí autori preto rozoznávajú niekol'ko stupňov a typov gramotností. Gavora (2006) spomína dva stupne gramotnosti - základnú a funkčnú. Zatial' čo prvý stupeň tvorí osvojenie si troch základných schopností vediet' čítat', písat' a počítat', funkčná gramotnost' nadväzuje na základné schopnosti a rozširuje ich. V odbornej literatúre sa rozlišuje gramotnost' čitatel'ská, matematická, prírodovedná, spoločenskovedná, ale tiež digitálna, mediálna, vedecká, občianska, multikultúrna, informačná či vývojárska (The Edvocate 2020). Jednotlivé typy gramotností sa navzájom ideovo prelínajú, na seba nadväzujú a dopíñajú sa. Často pritom nie je možné nadobudnút' vyššiu úroveň jednej gramotnosti bez toho, aby si jedinec neosvojil aspoň základnú úroveň iného typu gramotností. 


\section{GEOGRAFICKÁ GRAMOTNOSŤ}

Geografická gramotnost' predstavuje konečný ciel' geografického vzdelávania. Geografická gramotnost' zastupuje to najpodstatnejšie, čo by mal jedinec z dosiahnutého geografického poznania vediet' a následne byt' schopný aplikovat' naučené, či už vo svojom osobnom alebo pracovnom živote (Wackershauserová 2018). Vymedzenie tohto pojmu v odbornej literatúre je nejednoznačné a líši sa aj pomenovanie tejto schopnosti jednotlivými autormi. Zatial' čo v slovenskej a českej odbornej literatúre sa používa najmä pojem geografická gramotnost', prípadne geografické myslenie, $\mathrm{v}$ anglosaských krajinách má termín geografická gramotnost' omnoho širší významový záber. Okrem najčastejšie používaného výrazu geographic literacy sa často používa slovné spojenie geo-literacy, geo-learning, thinking geographically alebo thinking through geography, prípadne výraz spatial thinking. Viacerí autori striktnejšie nerozlišujú medzi geografickým myslením a geografickou gramotnost'ou.

Vymedzeniu pojmu geografická gramotnost' venovalo pozornost' viacero autorov a inštitúcií. Niektorí odborníci spájajú geografickú gramotnost' so schopnost'ou lokalizovat' miesto na mape, ked’že práve táto schopnost' jedinca poskytuje podl'a ich názoru pevný základ pre štúdium geografie (Torrens 2002 a Winship 2004). Dokázat' správne čítat' obsah mapy považujú za dôležité aj autori štúdie Geografická negramotnost' vysokoškolských študentov (Eve et al. 1994). Zároveň však dodávajú, že súčast'ou geografickej gramotnosti je tiež schopnost' preukázat' znalost' priestorovej analýzy miest a porozumiet' odlišným národom a kultúram spojeným s rozličnými regiónmi. Bein (1990) uznáva, že schopnost' lokalizácie miest na mape je dôležitá, no zdôrazňuje, že táto schopnost' nevyjadruje koncepčný rozsah geografických vedomostí. Appel (2020) chápe geografickú gramotnost' v kontexte geopriestorovej informačnej gramotnosti, ktorá pracuje s témami, ako sú kl'účové geografické koncepty, primárne zdroje a schopnosti súvisiace s mapou a priestorom.

Časopis National Geographic, ako svetový líder v geografickom vzdelávaní, ktorý sa najviac zaslúžil o popularizáciu geografie, definuje geografickú gramotnost' ako schopnost' využívat' geografické porozumenie a geografické zdôvodnenia pri robení dôležitých rozhodnutí s dlhodobým účinkom (National Geographic Society 2020). Geografickú gramotnost' tvoria podl'a Edelsona (2012) tri základné komponenty: interakcie, prepojenia a dôsledky.

Interakcie - geograficky gramotný človek chápe, že svet je zložený z prepojených a vzájomne sa ovplyvňujúcich systémov, ktoré sa hýbu a transformujú zdroje. Môžu to byt' systémy sociálne, politické, ekonomické, ale aj kultúrne, technologické - ako napríklad doprava, prenos energie, komunikačné, prípadne systémy životného prostredia - hydrologické, atmosférické a ekologické systémy.

Prepojenia - geograficky gramotný človek chápe, že tieto systémy navzájom prepájajú l'udí a miesta. To znamená, že udalosti, ku ktorým dôjde na jednom mieste, majú vplyv na iných l'udí a iné miesta. Takisto to znamená, že naše činy ovplyvňujú ostatných l'udí a miesta.

Dôsledky - geograficky gramotný človek je schopný pochopit' interakcie a prepojenia a využit' ich pri robení správnych a odôvodnených rozhodnutí. To znamená, že dokáže predvídat' následky činov, ktoré sú výsledkom interakcií systémov a prepojení medzi l'ud'mi a miestami. Takisto to znamená, že človek je schopný pri 
rozhodovaní zvážit' plusy a mínusy daného rozhodnutia, ktoré bude ovplyvňovat' nielen jeho, ale aj ostatných l'udí a miesta.

V takto obšírne chápanej geografickej gramotnosti dokážeme identifikovat' viaceré špecifické typy gramotnosti, ako sú gramotnost’ kartografická, informačná, environmentálna či geoinformačná. Stansfield (2002) dokonca geografickú gramotnost' vníma iba ako podmnožinu geoinformačnej, do ktorej okrem geografickej zarad'uje aj gramotnost' kartografickú a informačnú. Napriek tomu, že geografická gramotnost' nie je odborníkmi chápaná jednotne, pre jej rozvoj je nevyhnutné zvyšovat' úroveň gramotností, ktoré sú v nej priamo obsiahnuté. Medzi také radíme najmä kartografickú, priestorovú a geoinformačnú.

Kartografická gramotnost' zahŕňa podl'a Pravdu (2001) znalost' čítania (prípadne aj jednoduchého využívania) máp a znalost' tvorby máp. Tvorba máp, ako aj špecifické spôsoby využívania máp, sú príznaky vyššieho stupňa kartografickej gramotnosti, ktorej vždy predchádza znalost’ čítania máp (Pravda 2003). V zahraničí sa často na označenie zručností súvisiacich so schopnost'ou rozumiet' obsahu máp a denne ich využívat' $\mathrm{v}$ osobnom alebo pracovnom živote používa termín „mapová“ gramotnost' (angl. map literacy). Olson (1976), Board (1978) a Morrison (1978) túto gramotnost' viažu najmä na referenčné mapy a zručnosti, ako sú vediet' s mapou „navigovat"“ alebo „merat"“. Clarke (2003) nadväzuje na ich práce a navrhuje použitie slovného spojenia funkčná mapová gramotnost' pre pomenovanie schopností rozumiet' mapám a využívat' ich v bežnom živote. Xie et al. (2018) definujú tzv. kvantitatívnu mapovú gramotnost', pod ktorou rozumie vedomosti (koncepty, zručnosti a poznatky) potrebné na správne čítanie, používanie, interpretáciu a porozumenie kvantitatívnych údajov geografickej povahy prezentovaných $\mathrm{v}$ geopriestorových zobrazeniach. S nárastom využívania moderných technológií a satelitných navigačných prístrojov sa viacerí autori zamýšl'ajú nad vplyvom týchto zariadení na kartografickú gramotnost' jedinca a jeho vnímanie geografického priestoru (Laurier a Brown 2008, Patel et al. 2008, Parker 2009 a Speake a Axon 2012).

Priestorové myslenie je podl'a U.S. National Academy of Sciense kl'účovou zložkou priestorovej gramotnosti (National Research Council 2006). Pre geografov je priestorová gramotnost' schopnost' mysliet' $\mathrm{v}$ priestore, mysliet' s priestorom a prostredníctvom priestoru, pričom byt' priestorovo zručný je čoraz cennejšie a podstatnejšie (Fujita et al. 2001, Cosgrove 2004 a Goodchild a Janelle 2010). Priestorová gramotnost' je výsledkom priestorového myslenia a priestorového uvažovania. Ak človek dokáže mysliet' a uvažovat' priestorovo, v priestore a o priestore, možno ho považovat' za priestorovo gramotného (Bednarz a Kemp 2011).

Radikálnu zmenu v nazeraní na svet a interakciu s ním priniesla implementácia geopriestorových technológií (GIS, DPZ - angl. RS remote sensing, GPS) do bežného života jedinca a spoločnosti. V kontexte všeobecného trendu nárastu využívania týchto technológií môžeme priestorovú gramotnost' vnímat' aj ako esenciálnu a pridat' ju medzi základné tri - písat', čítat' a počítat' (Goodchild 2006 a Bednarz a Kemp 2011). Schopnost' zmysluplného využitia digitálnych technológií pri zvládaní bežných životných situácií a robení efektívnych rozhodnutí charakterizujú niektorí autori ako geoinformačnú gramotnost'. Geoinformačná gramotnost' je komplexným pojmom, zloženým z troch úrovní. Tie zahŕňajú chápanie, využívanie a vývoj. Využívanie geoinformačných technológií je znakom vyššej úrovne geoinformačnej gramotnosti, ked’že predchádza schopnosti chápat' geoinformačnú problematiku (Voženílek 2009). 


\section{VÝSKUMY GEOGRAFICKEJ GRAMOTNOSTI}

Zatial' čo na území Slovenska a Česka nebol doposial' realizovaný dôkladnejší výskum venovaný geografickej gramotnosti, v zahraničí je situácia o niečo priaznivejšia. Najväčšie množstvo výskumných aktivít zacielených na zist'ovanie úrovne geografickej gramotnosti populácie sa uskutočnilo na celonárodnej alebo regionálnej úrovni v Spojených štátoch amerických. Zaujímavé výsledky priniesli najmä výskumy americkej spoločnosti National Geographic Society, ktorá v spolupráci s výskumnou agentúrou Roper uskutočnila viacero výskumov geografickej gramotnosti.

Výsledky prvého výskumu v roku 1988 ukázali nízku úroveň geografických vedomostí občanov USA, a to najmä mladých l'udí vo veku 18 až 24 rokov (Maconochie 1988). Táto skutočnost' podnietila spoločnost' National Geographic zrealizovat' v roku 2002 d'alší výskum pod názvom Global Geographic Literacy Survey. Výskumu sa zúčastnilo 3250 mladých l'udí vo veku osemnást' až dvadsat'štyri rokov pochádzajúcich z deviatich vyspelých krajín sveta. Každú krajinu reprezentovalo 300 respondentov, pričom v USA bolo okrem 300 Američanov vo veku 18 až 24 rokov do výskumu zahrnutých aj viac ako 300 respondentov vo veku 25 až 40 rokov. Výskum vo všetkých krajinách prebiehal formou 15 - 25-minútových rozhovorov v domácom prostredí. Najvyššiu úroveň geografickej gramotnosti dosiahli respondenti zo Švédska, ktorých úspešnost' riešenia 56 otázok predstavovala $71 \%$. Na druhom a tret'om mieste sa zhodne umiestnili mladí l'udia z Nemecka a Talianska, ktorí odpovedali správne na 38 otázok (68\%). Za nimi nasledovali Francúzi (61\%), Japonci (55\%) a respondenti z Vel'kej Británie s 50 \% úspešnost’ou odpovedí. Najmenej úspešnú trojicu štátov reprezentovala Kanada s úspešnost’ou $48 \%$, Spojené štáty americké (41\%) a Mexiko, ktorého respondenti odpovedali správne na menej ako tretinu otázok (21), čo predstavuje približne $38 \%$ úspešnost'. Počet správnych odpovedí respondentov z jednotlivých štátov je znázornený na obr. 1 .

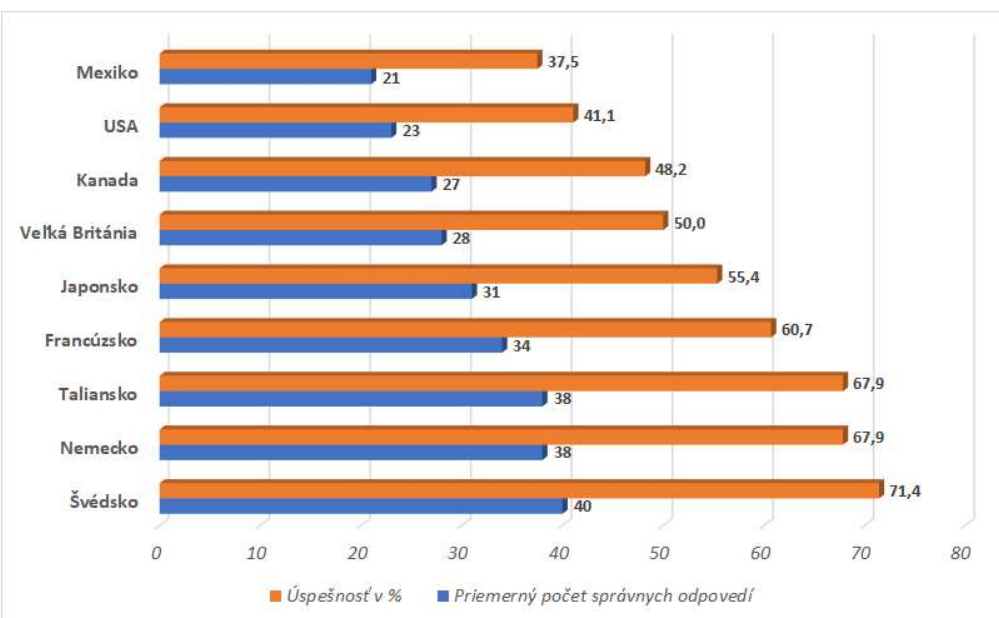

Obr. 1. Úspešnost' odpovedí respondentov zúčastnených na výskume Global Geographic Literacy Survey 
Porovnanie výsledkov výskumov realizovaných v roku 1988 a 2002 ukázalo, že za 14 rokov nedošlo prakticky k žiadnemu výraznému zvýšeniu úrovne geografickej gramotnosti. Najalarmujúcejším zistením bol fakt, že až približne $11 \%$ respondentov zo Spojených štátov amerických nedokázalo nájst' na obrysovej mape sveta vlastnú krajinu a iba $50 \% \mathrm{z}$ nich dokázalo na mape správne umiestnit' štát New York. Určit' Tichý oceán nedokázalo až 29 \% Američanov a Spojené král'ovstvo nevedelo na mape správne identifikovat' až 69 \% z nich. Na druhej strane sa výskumom potvrdila hypotéza, že vedomosti z geografie priamo súvisia s cestovaním a znalost'ou cudzích jazykov. V krajinách s najvyššou dosiahnutou úspešnost'ou správnych odpovedí, t. j. vo Švédsku, Nemecku a Taliansku, viac ako $70 \%$ mladých l'udí vycestovalo $\mathrm{v}$ posledných troch rokoch za hranice vlastného štátu a väčšina z nich ovládala viac ako jeden cudzí jazyk. Naopak, respondenti pochádzajúci zo štátov, ktoré obsadili posledné dve priečky (Mexiko a USA), vycestovali do zahraničia iba približne v 20 \% prípadov a väčšina z nich hovorila iba jedným (materinským) jazykom (Roper 2002).

V poradí tretí výskum zastrešený spoločnost'ou National Geographic a agentúrou Roper bol realizovaný v roku 2006. Tentokrát sa výskum sústredil iba na obyvatel'ov Spojených štátov amerických. Výskum sa realizoval na prelome rokov 2005 a 2006 a zúčastnilo sa ho 510 respondentov vo veku 18 až 24 rokov. Aj tento výskum potvrdil, že mladým l'ud'om žijúcim v USA chýbajú základné geografické vedomosti. Najväčší problém im robilo správne určit' polohu štátov Blízkeho východu. Hoci izraelsko-palestínsky konflikt bol a stále je v USA vel'mi živou témou, až $75 \%$ respondentov nedokázalo na obrysovej mape samotný štát Izrael nájst'. Irán nevedelo vyhl'adat' $74 \%$ respondentov a $63 \%$ nedokázalo správne lokalizovat' Irak a Saudskú Arábiu. Skoro polovica z nich (44 \%) nebolo schopných určit' na mape ani jednu z týchto štyroch krajín. Až 30 \% respondentov nedokázalo nájst' na mape sveta Č́nu a 7 z 10 respondentov nebolo schopných správne lokalizovat' Kórejskú l'udovodemokratickú republiku. Dve tretiny respondentov nepovažovalo za najstráženejšiu hranicu na svete hraničnú líniu medzi Kórejskou l'udovodemokratickou republikou a Kórejskou republikou, ale hranicu medzi Mexikom a Spojenými štátmi americkými. Vel'ký problém mali mladí l'udia z USA s orientáciou v priestore a schopnost'ou správne určit' smer úniku z mesta ohrozeného hurikánom (Roper 2006).

Okrem výskumov geografickej gramotnosti dospelých l’udí prebiehajú v Spojených štátoch amerických aj výskumy geografickej gramotnosti školopovinných detí vo veku 13 až 14 rokov. Tieto výskumy sa realizujú v pravidelných štvorročných intervaloch pod záštitou amerického Úradu vlády pre zodpovednost' (The United States Government Accountability Office - GAO) od roku 1994 s názvom National Assessment of Educational Progress - Geography Assessment. Posledný takýto výskum sa konal v roku 2018. Ked’že jeho výsledky neboli doposial' zverejnené, uvádzame zistenia z testovania, ktoré sa konalo v roku 2014 (GAO 2015). Výsledky výskumu potvrdili nízku úroveň geografickej gramotnosti aj u školopovinných detí. Hoci GAO zverejnila iba výsledky žiakov ôsmych tried, alarmujúcou ostáva skutočnost'ou, že až takmer 3/4 žiakov nepreukázali v testoch dostatočné geografické vedomosti a od roku 1994 takmer žiadne zlepšenie. Porovnanie dosiahnutej úrovne geografickej gramotnosti žiakov ôsmych tried v Spojených štátoch amerických v roku 1994 a 2014 uvádza obr. 2. 


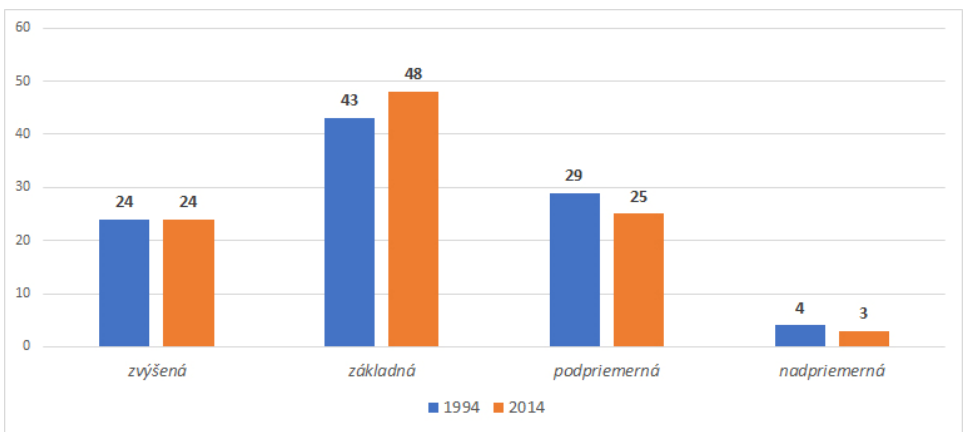

Obr. 2. Porovnanie dosiahnutej úrovne geografickej gramotnosti 13- až 14-ročných Američanov v rokoch 1994 a 2014 v \%

(United States Government Accountability Office 2015)

\section{AKÁ JE GEOGRAFICKÁ GRAMOTNOSŤ MLADÝCH L'UDÍ NA SLOVENSKU?}

\section{Ciele výskumu a výskumné otázky}

Ciel’om nášho výskumu bolo zistit’ dosiahnutú úroveň geografickej gramotnosti u mladých l’udí na Slovensku vo veku 18 až 24 rokov. Zároveň sme analyzovali postoje a názory mladých Slovákov na geografiu, vnímanie dôležitosti geografie v súčasnom svete a geografické vedomosti súvisiace so schopnostou respondentov správne sa orientovat' $\mathrm{v}$ aktuálnom dianí doma i vo svete. Realizáciou výskumu sme sa zamerali na zodpovedanie nasledujúcich výskumných otázok:

- Aká je úroveň geografickej gramotnosti Slovákov vo veku 18 až 24 rokov?

- Aké faktory ovplyvňujú dosiahnutú úroveň geografickej gramotnosti Slovákov vo veku 18 až 24 rokov?

\section{Výskumný nástroj a jeho charakteristika}

$\mathrm{Na}$ výskum geografickej gramotnosti mladých l’udí na Slovensku sme zvolili upravený výskumný nástroj použitý pri výskume National Geographic - Roper 2002 Global Geographic Literacy Survey (Roper 2002). Ten bol skonštruovaný medzinárodnou výskumnou agentúrou RoperASW na žiadost' spoločnosti National Geographic. Vol'ba už použitého výskumného nástroja nám umožnila s časovým odstupom porovnat' dosiahnutú úroveň geografickej gramotnosti mladých l'udí na Slovensku s ich rovesníkmi žijúcimi v iných vyspelých krajinách sveta.

Ked'že nami realizovaný výskum prebiehal oproti pôvodnému výskumu elektronicky a nie formou osobných rozhovorov $\mathrm{v}$ domácom prostredí respondenta, urobili sme pri jeho lokalizácii do slovenského jazyka viaceré formálne zmeny a úpravy. Zároveň sme nahradili niektoré pôvodné položky zamerané na orientáciu v obrysovej mape Ameriky a správne odhady počtu obyvatel'ov amerických štátov tematicky podobnými úlohami, ktoré lepšie zohl’adňovali slovenské reálie a národné vzdelávacie programy. Respondenti na Slovensku tak namiesto názvov amerických štátov určovali slovenské mestá a pracovali s počtami obyvatel'ov Slovenska a štátov tvoriacich Európsku úniu. Každú otázku z pôvodnej verzie výskumného nástroja sme podrobili dôkladnej odbornej analýze a posúdili jej relevantnost', aktuálnost', vhodnost' a zrozumitel'nosti pre slovenského respondenta. 
Z mapových podkladov sme z pôvodných máp využili iba mapu sveta (obr. 3), na ktorej respondenti identifikovali štáty pomocou čísel. Ostatné mapové diela použité v našom výskumnom nástroji sme pri zachovaní pôvodného obsahu nanovo vytvorili.

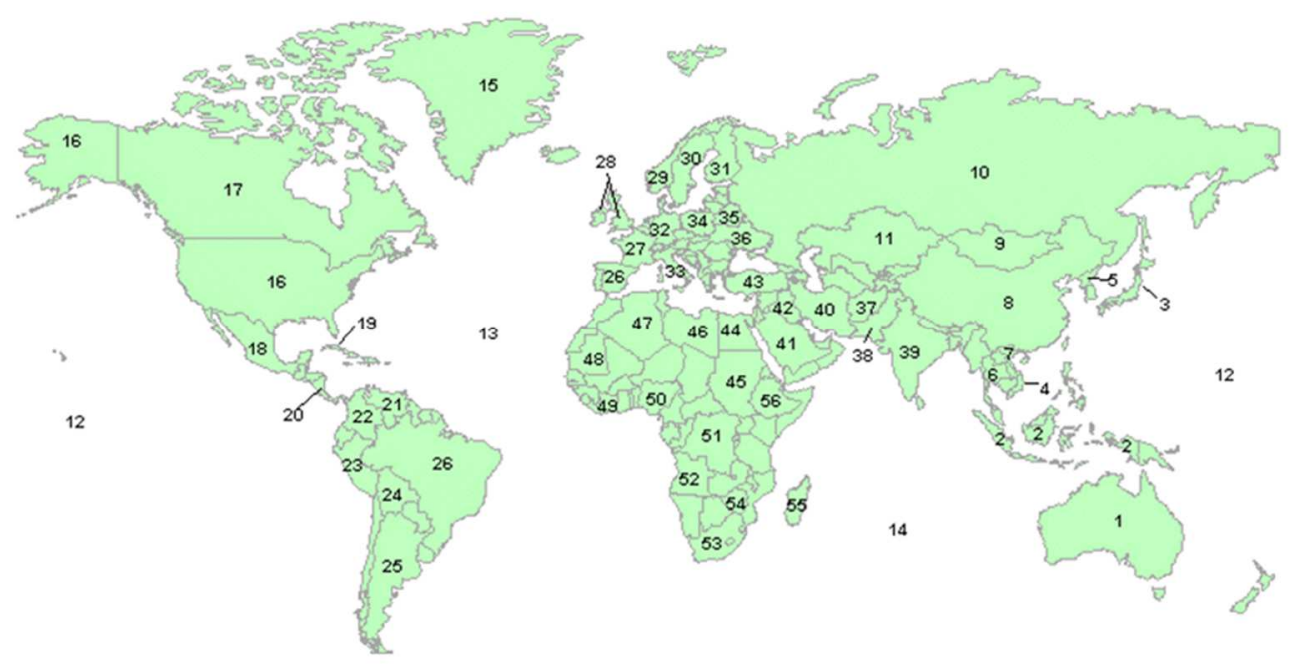

Obr. 1. Mapa sveta použitá vo výskume geografickej gramotnosti mladých l'udí na Slovensku

Zdroj: Roper (2002).

Pre administrovanie elektronickej verzie dotazníka sme zvolili profesionálne testovacie prostredie systému ClassMarker s automatizovaným posudzovaním a vyhodnocovaním správnosti odpovedí. Pri otvorených otázkach sme požiadali respondentov, aby názvy krajín písali v základnom tvare. Program uznal za správnu odpoved' aj gramaticky nesprávne napísaný názov alebo názov, v ktorom respondent nerozlišoval medzi vel'kými a malými písmenami.

Podobne, ako to bolo v pôvodnom výskume geografickej gramotnosti, aj slovenskí respondenti boli poučení, aby si namiesto tipovania správnej odpovede na otázky vybrali radšej možnost', ,neviem“.

Výskumný nástroj bol zložený z troch častí, z ktorých úvodná obsahovala otázky v uzatvorenom formáte so škálovanou odpoved’ou a posledná, tretia uzatvorené otázky s výberom odpovedí. Nosnou a rozsahom najväčšou častou výskumného nástroja bola jeho druhá čast' zahŕňajúca vedomostný test.

\section{Názory a postoje}

V prvej časti elektronického dotazníka respondenti odpovedali na šest' uzatvorených otázok, ktoré boli doslovne prevzaté z výskumu National Geographic. Respondenti $\mathrm{v}$ nich posudzovali mieru dôležitosti vybraných zručností $\mathrm{v}$ dnešnom svete tak, že si vyberali jednu zo štyroch ponúkaných alternatív odpovedí (je to nevyhnutne potrebné, dôležité, ale nie nevyhnutne potrebné, nie také dôležité) a pokial' si neboli istí, mohli sa rozhodnút' pre možnost' neviem. Medzi hodnotenými spôso- 
bilost'ami boli napr. schopnost' vediet' používat' počítač, vediet' čítat' mapu, vediet' napísat' oficiálny list či ovládat' cudzí jazyk.

\section{Svet a dianie vo svete}

Vedomostná čast’ testu nazvaná „Svet a dianie vo svete“ bola rozdelená na dve sekcie - vedomosti o svete a mapové zručnosti.

a) Sekcia vedomostí o svete

V pôvodnom výskume geografickej gramotnosti tvorilo túto sekciu 14 otázok. V našom výskume pozostávala sekcia vedomostí o svete zo 16 otázok, pričom sme jednu úlohu $\mathrm{z}$ pôvodného výskumu odstránili a pridali nasledujúce tri nové úlohy.

- V ktorom z nasledujúcich rozpätí je správne určený počet obyvatel'ov Európskej únie?

- Ku ktorým z nasledujúcich environmentálnych problémov môže viest' neustále zvyšovanie emisií oxidu uhličitého? (Otázka má viacero správnych odpovedí).

- Ktorá z nasledujúcich etnických skupín je najväčšou nearabskou menšinou v Iraku?

$\mathrm{Z}$ vedomostného testu bola odstránená úloha:

- Viete vymenovat' štyri krajiny, ktoré oficiálne disponujú jadrovými zbraňami a sú považované za jadrové vel'moci?

Zadanie d'alších troch pôvodných otázok bolo v našom výskume pozmenené, pričom ale výsledná geografická vedomost', ktorú dané úlohy zistovali, ostala nezmenená. Išlo o otázky:

- Z ktorej krajiny pochádza väčšina imigrantov, ktorí prichádzajú do Európy? (Názov krajiny napíste, prosím, v základnom tvare). V pôvodnom výskume National Geographic sa výskumníci pýtali respondentov, odkial' pochádza väčšina imigrantov smerujúcich do Spojených štátov amerických.

- Mnohé scény v jednom z najobl'úbenejších seriálov všetkých čias, Game of Thrones, sa natáčali v Dubrovníku. Ktoré more obmýva pobrežie tohto mesta? Respondenti $\mathrm{v}$ pôvodnom výskume odpovedali na otázku, v ktorom oceáne sa nachádza ostrov Tahiti. Otázka bola inšpirovaná vel'kou popularitou v tom čase vysielanej televíznej show „Survivor“.

- Ktorá z nasledujúcich krajín nepatrí medzi najväčších producentov ropy na svete? Pôvodná otázka zist'ovala, ktorý svetový región je najväčším vývozcom ropy. Ked'že výsledky tohto výskumu ukázali, že vyše $80 \%$ všetkých respondentov odpovedalo na otázku správne, rozhodli sme sa túto otázku preformulovat’ a zamerat' sa viac na konkrétne krajiny, najmä tie európske.

- Ktoré štáty majú viac ako jednu miliardu obyvatel'ov? Pôvodná formulácia otázky vyzývala respondentov, aby si vybrali zo zoznamu krajín dve, ktoré majú viac ako jednu miliardu obyvatel'ov. Zoznam krajín však v prílohe výskumu nebol uvedený, preto sme si vytvorili vlastný zoznam, ktorý zahŕn̆al okrem možnosti „neviem“ devät' krajín zo Severnej a Južnej Ameriky, Afriky, Ázie a Európy.

b) Sekcia mapových zručností

Druhá sekcia testu skúmala úroveň mapových zručností respondentov. Táto čast' bola v porovnaní s výskumom National Geographic výrazne skrátená a z pôvodných 51 otázok obsahovala iba 32. Skrátená bola sekcia otázok venovaná určeniu správnej polohy vybraných štátov v mape sveta. Z pôvodných 49 otázok sme 
do nášho výskumu z časových dôvodov zaradili iba 28. Konkrétne rozdiely sú uvedené v tabul'ke 1.

Tab. 1. Porovnanie počtu otázok (n) mapových zručností a určovania polohy medzi oboma výskumami

\begin{tabular}{l|l}
\hline \multicolumn{1}{c|}{ Výskum National Geographic $(\mathrm{n}=51)$} & \multicolumn{1}{c}{ Nami realizovaný výskum $(\mathrm{n}=32)$} \\
\hline A. mapové zručnosti & A. mapové zručnosti \\
- navigácia $(\mathrm{n}=2)$ & - navigácia $(\mathrm{n}=2)$ \\
& - čítanie obsahu mapy $(\mathrm{n}=2)$ \\
& B. určenie polohy \\
B. určenie polohy & - svet $(\mathrm{n}=15)$ \\
- svet $(\mathrm{n}=16)$ & - slovenské mestá $(\mathrm{n}=8)$ \\
- americké mestá $(\mathrm{n}=10)$ & - Blízky východ $(\mathrm{n}=5)$ \\
- Ázia $(\mathrm{n}=11)$ & \\
- Európa $(\mathrm{n}=12)$ & \\
\hline
\end{tabular}

Úlohy týkajúce sa navigačných schopností ostali nezmenené, pozmenené boli iba názvy miest, ked’že sme pri týchto otázkach použili reálnu obrysovú mapu so skutočnými mestami.

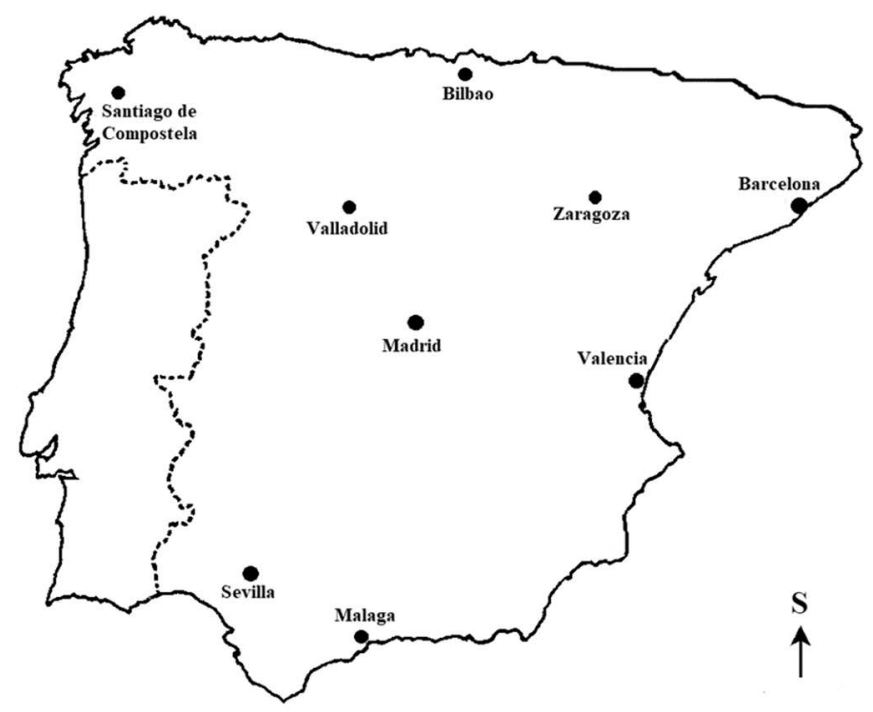

Obr. 4. Mapa Španielska použitá v teste geografickej gramotnosti mladých l'udí na Slovensku

Do nami realizovaného výskumu sme zaradili aj dve otázky týkajúce sa schopnosti vediet' správne čítat' obsah mapy, ktoré pôvodný výskum geografickej gramotnosti National Geographic neobsahoval. Pri ich tvorbe sme sa inšpirovali iným americkým výskumom geografickej gramotnosti, ktorý vo svojej práci publikoval Winship (2004). Tieto otázky testovali, do akej miery dokážu respondenti správne 
porozumiet' legende kartogramu zobrazeného v mape, navigovat' a orientovat' sa v obsahu obrysovej (obr. 4) alebo turistickej mapy s vrstevnicami. Dôvodom zaradenia týchto otázok do výskumu bola snaha o poskytnutie vyváženejšieho hodnotenia mapových zručností respondentov.

$\mathrm{V}$ porovnaní s prieskumom realizovaným na podnet National Geographic sa počet otázok tematicky zacielených na správnu lokalizáciu krajín a miest znížil z dôvodu zachovaniu časového limitu 18 minút zo 49 na 28 otázok. Zmenili sa i krajiny, ktoré mali respondenti správne identifikovat' na mapách. Pre náš výskum sme použili tri mapy - mapu sveta, mapu Blízkeho východu a mapu slovenských miest. Mapu Európy vo výskume National Geographic sme odstránili najmä pre časové obmedzenia a namiesto celej Ázie sme sa zamerali na región Blízkeho východu, ktorému médiá venovali v čase administrácie elektronického dotazníka zvýšenú pozornost'.

Počet otázok zameraných na určenie polohy vybraných krajín a miest na mape sveta bol v konečnom výsledku znížený iba o jednu otázku, zo 16 otázok na 15. Výber krajín, ktoré mali respondenti na mape správne lokalizovat', bol upravený tak, aby odzrkadl'oval lepšie celosvetové zastúpenie krajín. Zároveň sme zobrali do úvahy aj aktuálne dianie vo svete a širšie medializované udalosti a problémy vo vybraných regiónoch (tab. 2).

Tab. 2. Porovnanie jednotlivých krajín a ich počtu (n), ktoré mali v oboch výskumoch respondenti lokalizovat' na mape

\begin{tabular}{l|l}
\hline Výskum National Geographic $(\mathrm{n}=16)$ & Nami realizovaný výskum $(\mathrm{n}=15)$ \\
\hline Spojené štáty americké & Spojené štáty americké \\
Rusko & Rusko \\
Argentína & Argentína \\
Japonsko & Japonsko \\
Francúzsko & Francúzsko \\
Mexiko & Mexiko \\
Spojené král'ovstvo Vel'kej Británie & Spojené král'ovstvo Vel'kej Británie \\
a Severného Îrska & a Severného IIrska \\
Tichý oceán & Tichý oceán \\
Egypt & Egypt \\
Nemecko & Nemecko \\
Kanada & India \\
Taliansko & Kórejská l'udovodemokratická republika \\
Afganistan & Nigéria \\
Švédsko & Pakistan \\
Izrael & Atlantický oceán \\
Kuba & \\
\hline
\end{tabular}

Súčast’ou výskumu realizovanom v roku 2002 pod gesciou National Geographic bola aj obrysová mapa Ázie. Túto mapu sme pre účely nášho výskumu nahradili mapou Blízkeho východu. Respondenti mali za úlohu správne určit' polohu Saudskej Arábie, Afganistanu, Izraela, Iraku a Iránu. Podobne ako to bolo pri iných častiach vedomostného testu, aj $\mathrm{v}$ tomto prípade bolo dôvodom zmeny pôvodných 
úloh časové obmedzenie. Región Blízkeho východu sme ako náhradu zvolili pre neustále pretrvávajúce nepokoje v tejto oblasti a ich častú medializáciu.

Poslednú čast' elektronického vedomostného testu tvorili otázky týkajúce sa určovania polohy slovenských miest. Respondenti mali za úlohu správne lokalizovat' krajské mestá na obrysovej mape Slovenska.

\section{Dotaznikové otázky}

V tejto časti výskumného nástroja sa zvolené otázky výrazne neodlišovali od tých, ktoré boli pokladané respondentom vo výskume National Geographic. Celkovo sme respondentom zadali osem dotazníkových otázok, pričom pôvodný výskum ich obsahoval desat'.

Dotazníkmi sme zist'ovali vek, pohlavie, najvyššie dosiahnuté vzdelanie respondentov, d’alej počet jazykov, ktoré respondenti ovládajú, a počet vycestovaní respondentov do zahraničia za posledné tri roky. Náš výskum sme doplnili o otázku, či respondenti na strednej škole mali okrem povinných hodín geografie aj d'alšie volitel'né hodiny geografie.

Oproti výskumu National Geographic sme do elektronického dotazníka určeného pre mladých l'udí zo Slovenska nezaradili otázku o možnosti využívania internetu, ked’že samotný test geografickej gramotnosti vyžadoval internetové pripojenie. Rovnako sme do obsahu dotazníka nezačlenili otázku, ktorý člen rodiny sa narodil v Spojených štátoch amerických ako prvý a otázku týkajúcu sa názvov novín a časopisov, ktoré respondenti pravidelne kupujú. Pri otázke zist'ujúcej odkial' respondenti primárne čerpajú informácie o aktuálnom dianí doma i vo svete sme mierne pozmenili zoznam ponúkaných informačných zdrojov.

\section{CHARAKTERISTIKA VÝSKUMNÉHO SÚBORU}

Výskumu geografickej gramotnosti mladých l’udí na Slovensku sa zúčastnilo celkovo 300 respondentov vo veku 18 až 24 rokov, z toho bolo 172 žien $(57,3 \%$ ) a 128 mužov (42,7 \%). Najviac zastúpená bola veková skupina 23-ročných respondentov $(20,7 \%)$, najmenš́i počet respondentov zúčastnených vo výskume mala kategória 18-ročných (4\%).

Tab. 3. Vekové zloženie respondentov zúčastnených na výskume geografickej gramotnosti

\begin{tabular}{ccc}
\hline Vek & Početnost & $\%$ \\
\hline 18 & 12 & $4,00 \%$ \\
19 & 26 & $8,67 \%$ \\
20 & 43 & $14,33 \%$ \\
21 & 54 & $18,00 \%$ \\
22 & 43 & $14,33 \%$ \\
23 & 62 & $20,67 \%$ \\
24 & 60 & $20,00 \%$ \\
\hline
\end{tabular}

Z pohl'adu najvyššieho dosiahnutého vzdelania tvorili najpočetnejšiu skupinu (111; 33,3 \%) absolventi gymnázií. Za ním nasledovali respondenti s vysokoškolským vzdelaním I. stupňa $(88 ; 29,4$ \%), stredným odborným vzdelaním s maturitou 
(55; 18,3 \%) a absolventi vysokoškolského vzdelania II. stupňa (45; 15 \%). Najmenšie zastúpenie mali respondenti bez vzdelania alebo $\mathrm{s}$ neúplným základným vzdelaním $(1 ; 0,3 \%)$, stredným odborným vzdelaním bez maturity $(5 ; 1,7 \%)$ a základným vzdelaním $(6 ; 2 \%)$.

\section{VÝSKUMNÉ METÓDY}

Výskum skúmajúci úroveň geografickej gramotnosti mladých l'udí na Slovensku bol realizovaný prostredníctvom online dostupného testovacieho systému ClassMarker a mal formu elektronického, automaticky vyhodnocovaného testu. Test bol pre respondentov dostupný online na internetovej adrese https:// www.classmarker.com/online-test/start/?quiz=qmd5f86db1e49102. Výber výskumného súboru mal charakter zámerného výberu a uskutočnil sa na prelome mesiacov jún/júl 2019. Respondenti boli požiadaní, aby počas testu pracovali samostatne a upozornení, že výsledky elektronického testovania budú anonymné, slúžia výhradne na výskumné účely a účast' na výskume je dobrovol'ná. Pred začatím testovania boli respondentom poskytnuté inštrukcie, ako majú pri jeho vypĺn̆aní postupovat'.

Štatisticky vyhodnocované boli iba vedomostné otázky, pričom za každú správnu odpoved' mohol respondent získat' jeden bod. Ked'že počet otázok vedomostného zamerania bol v elektronickom teste 48, najvyššie možné hrubé bodové skóre predstavovalo 48 bodov.

Validita lokalizovanej verzie testu geografickej gramotnosti mladých l'udí na Slovensku bola overená piatimi didaktikmi a učitel'mi geografie. Pre zistenie spol'ahlivosti použitého výskumného nástroja sme použili koeficient Cronbachovo alfa. Cronbachovo alfa nadobudlo hodnotu 0,88 , čo značí vysokú vnútornú konzistenciu a spol'ahlivost' testu. Výsledky a výskumné zistenia týkajúce sa úrovne geografickej gramotnosti mladých l'udí na Slovensku možno preto považovat' za spol'ahlivé.

$\mathrm{Na}$ zistenie normálneho rozdelenia dát sme využili Shapiro-Wilkov test, ktorý zamietol normálne rozdelenie dát $(0,97 ; \mathrm{p}<0,05)$. Na porovnanie výsledkov sme preto použili neparametrické alternatívy testov. Na porovnanie významnosti rozdielov medzi viacerými súbormi sme použili Kruskal-Wallisov test. Ide o neparametrickú alternatívu jednofaktorovej analýzy rozptylu (one-way ANOVA), ktorá testuje významnost' rozdielov v mediánoch, respektíve v rozdelení premennej medzi viacerými súbormi. Ako post hoc test sme aplikovali Bonferroniho test. Na zistenie miery závislosti medzi dvoma alebo viacerými premennými sme použili Spearmanov korelačný koeficient používaný pre intervalové premenné, ktoré nemajú normálne rozloženie.

\section{VÝSLEDKY}

\section{Názory respondentov na vybrané zručnosti a vedomosti}

Prvých šest’ dotazníkových otázok výskumného nástroja malo za úlohu zistit' názory a stanoviská respondentov $\mathrm{k}$ šiestim zručnostiam, ktoré sú potrebné v dnešnom svete.

a) Vediet' používat' počítač

Až 198 respondentov $(66 \%)$ v elektronickom dotazníku uviedlo, že táto zručnost' je v dnešnom svete nevyhnutne potrebná. Za dôležitú, ale nie nevyhnutne po- 
trebnú ju považovalo 33,7 \% respondentov a iba jeden respondent označil túto zručnost' za nie takú dôležitú.

b) Vediet' č́tat' mapu

Dvestošest' respondentov $(68,7 \%$ ) považovalo zručnost' vediet' čítat' mapu za dôležitú, ale nie nevyhnutne potrebnú. Za nevyhnutne potrebnú ju pokladalo 49 respondentov (16,3\%) a $44(14,7 \%)$ ju nepovažovalo za takú dôležitú.

c) Vediet' napísat' oficiálny list

Vediet' napísat' oficiálny list (napr. žiadost') pokladalo $148(49,3 \%)$ respondentov za nevyhnutne potrebné a $131(43,7 \%)$ respondentov za dôležité, aj ked' nie nevyhnutne potrebné. Dvadsat' $(6,7 \%)$ respondentov vyjadrilo názor, že táto zručnost' nie je v dnešnom svete potrebná.

d) Ovládat' cudzi jazyk

Aj ked' sme očakávali, že väčšina respondentov označí túto zručnost' ako nevyhnutne potrebnú, v skutočnosti sa pre ňu rozhodlo $174(58,0 \%)$ respondentov. Ǎž $121(40,3 \%)$ respondentov nepovažovalo túto zručnost' za nevyhnutne potrebnú, aj ked' je podl'a ich názoru dôležitá.

e) Vediet', kde sa nachádzajú jednotlivé štáty sveta

Vediet', kde sa nachádzajú jednotlivé štáty sveta, bola jediná zručnost', o ktorej sa väčšina respondentov nevyjadrila, že je $\mathrm{v}$ dnešnom svete nevyhnutne potrebná alebo aspoň dôležitá. Hoci sa až $181(60,3$ \%) respondentov zhodlo na skutočnosti, že je táto zručnost' dôležitá, $95(31,7,0 \%)$ respondentov ju označilo za nie takú dôležitú. Iba $24(8,0$ \%) respondentov ju zaradilo medzi nevyhnutne dôležité vedomosti.

f) Mat' prehl'ad o súčasnom dianí doma i vo svete

Posledná otázka sa zameriavala na zist'ovanie názorov respondentov na to, či je dôležité mat' prehl'ad o súčasnom dianí doma i vo svete. Až 195 (65\%) respondentov sa zhodlo v názore, že táto zručnost' je síce dôležitá, ale pre život nie nevyhnutne potrebná.

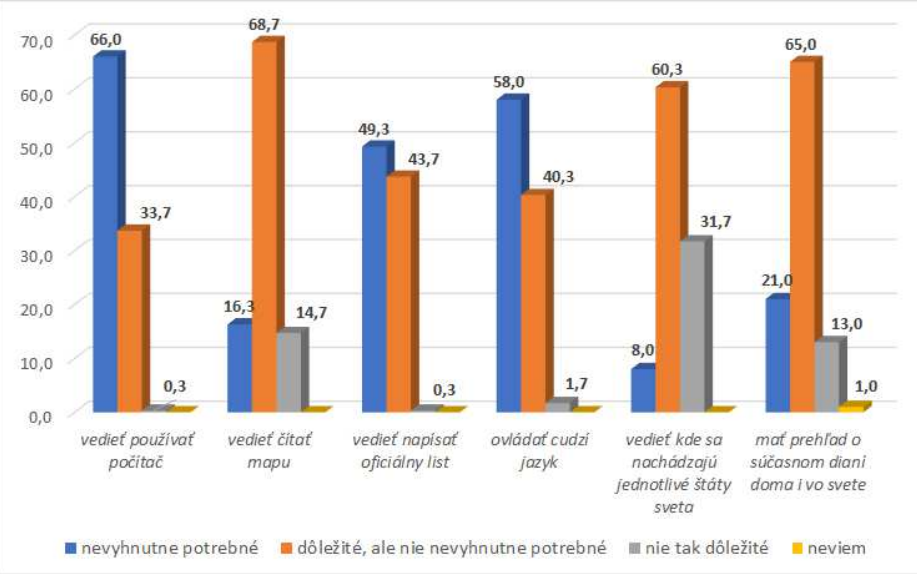

Obr. 5. Dôležitost' skúmaných zručností z pohl'adu respondentov zúčastnených na výskume (v \%) 
Faktory ovplyvňujúce úroveň geografickej gramotnosti

V dotazníkovej časti sme sa respondentov pýtali aj na vybrané faktory, ktoré by mohli ovplyvnit' dosiahnutú úroveň geografickej gramotnosti.

a) Počet plynulo ovládaných cudzích jazykov

Väčšina oslovených respondentov $173(57,7 \%)$ uviedla, že ovláda plynulo jeden cudzí jazyk. Dva cudzie jazyky ovládalo 91 (30,3\%) respondentov a 21 $(7,0 \%)$ respondentov neovládalo ani jeden cudzí jazyk. Medzi všetkými respondentmi bolo iba $15(5,0 \%)$ takých, ktorí plynulo ovládali tri a viac cudzích jazykov. Pripomíname, že pri elektronickom administrovaní tejto otázky sme respondentov požiadali, aby do konečného počtu ovládaných cudzích jazykov nepočítali český jazyk.

b) Počet vycestovani do zahraničia za posledné tri roky

Analýza odpovedí na túto otázku potvrdila, že mladí l’udia vo veku 18 až 24 rokov radi cestujú do zahraničia. Až 177 (59,0\%) respondentov označilo, že $\mathrm{v}$ priebehu posledných troch rokov vycestovali do zahraničia viac ako trikrát. Dvakrát za posledné tri roky do zahraničia vycestovalo $57(19,0 \%)$ respondentov, raz $36(12,0 \%)$ respondentov a ani jedenkrát nevycestovalo $30(10,0 \%)$ respondentov.

c) Počet hodín geografie na strednej škole

Viac ako 2/3 respondentov (74,3\%) nemali okrem povinných vyučovacích hodín geografie d'alšie, volitel'né vyučovacie hodiny geografie. Tie malo na strednej škole iba $68(22,7 \%)$ respondentov a $9(3,0 \%)$ respondentov si na túto skutočnost' nevedelo spomenút'.

d) Frekvencia vyhl'adávania informácii o diani doma $i$ vo svete

Väčšina respondentov (38,7 \%) sa zhodla v názore, že informácie spojené s dianím doma a vo svete vyhl'adávajú nepravidelne, resp. podl'a potreby. Sedemdesiatdevät' respondentov $(26,3 \%)$ vyhl'adáva informácie spojené s dianím doma i vo svete každý deň. Frekvenciu odpovedí na túto otázku uvádzame na obr. 2.

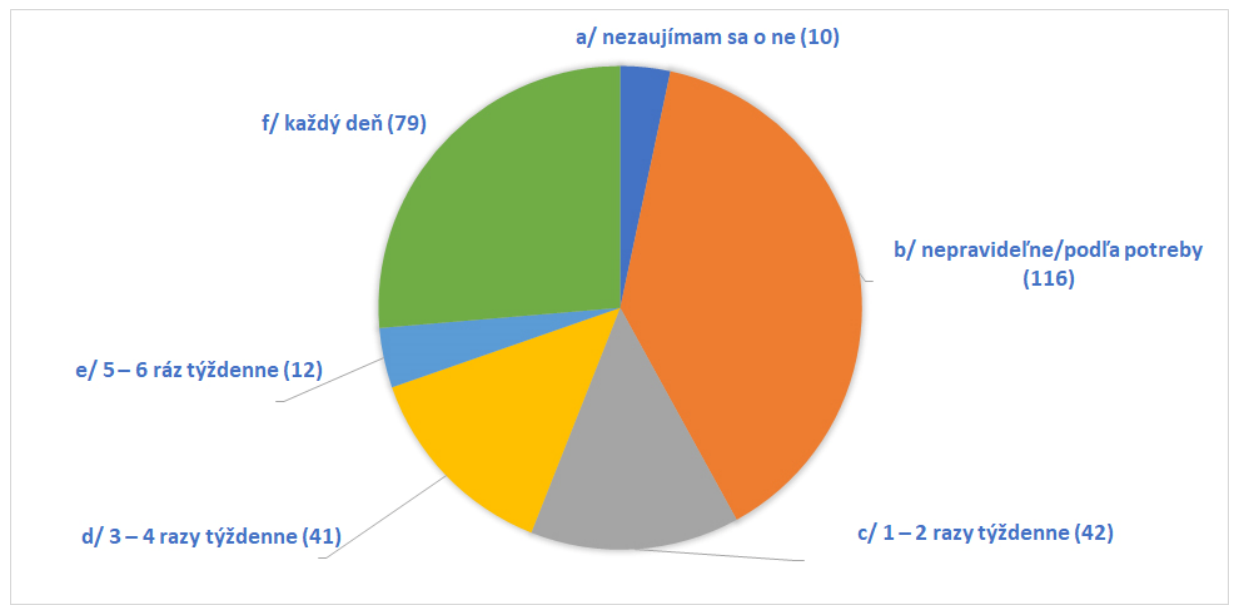

Obr. 6. Frekvencia vyhl'adávania informácií o dianí doma i vo svete respondentmi 


\section{e) Zdroje čerpania informácii}

V súlade s naším predpokladom takmer všetci respondenti $(281 ; 93,7$ \%) čerpajú informácie o súčasnom domácom alebo svetovom dianí prostredníctvom webových stránok. Za týmto verejne dostupným systémom prepojenia počítačových sietí nasleduje jedna $z$ najoblúbenejších webových služieb určená na nadväzovanie a udržiavanie kontaktov medzi l'ud'mi - sociálne siete $(192 ; 64,0 \%)$, d'alej je to televízia $(118 ; 69,3 \%)$ a rodina spolu s priatel'mi $(108 ; 36 \%)$. Informácie o domácom a svetovom dianí čerpá z novín a časopisov 84 (28,0\%) respondentov a $\mathrm{z}$ rádia 76 $(25,3 \%)$.

\section{GEOGRAFICKÁ GRAMOTNOSŤ MLADÝCH LUDÍ NA SLOVENSKU}

Test vyplnilo celkovo 300 respondentov. Priemerný čas riešenia testu bol 13 minút a 7 sekúnd. Respondenti mohli získat' maximálne 48 bodov. Priemerný počet bodov zúčastnených respondentov bol 34,2 (SD =7,44), čo predstavuje percentuálne skóre 71,2 \%. Úspešnost' $90 \%$ a viac dosiahlo 23 respondentov $(7,7 \%)$, z ktorých traja respondenti dokončili test so $100 \%$ úspešnost'ou. To predstavuje iba 1,0 \% všetkých respondentov. Jeden respondent dosiahol skóre 97,9 \% (47 správnych odpovedí zo 48). Naopak, jedenást' respondentov (3,7\%) dosiahlo skóre menšie ako $40 \%$. Finálne skóre dvoch respondentov bolo $27,1 \%$, čo predstavuje iba 13 správne zodpovedaných otázok zo 48. Zároveň ide o celkovo najmenšie dosiahnuté skóre $\mathrm{v}$ tomto teste. Otázky s najvyššou úspešnost'ou sa týkali umiestnenia slovenských miest na mape - konkrétne mestá Bratislava (98,3 \%) a Banská Bystrica $(97,7 \%)$. Na druhej strane, otázky s najnižšou úspešnost'ou sa týkali umiestnenia Nigérie na mape sveta $(26,0 \%)$ a Iraku na mape Blízkeho východu $(31,3 \%)$.

Zaujímalo nás, či respondenti, ktorí oceňujú význam a potrebu prehl'adu v súčasnom dianí doma a vo svete, majú aj vyššiu úroveň geografickej gramotnosti. Statistická analýza prostredníctvom Kruskal-Wallisovho testu ukázala, že medzi skupinami neexistuje štatisticky významný rozdiel $(6,12 ; p>0,05)$, ale existuje rozdiel vo vedomostiach respondentov o svete $(10,50 ; \mathrm{p}<0,05)$. Post hoc test ukázal, že respondenti, ktorí uviedli, že prehl'ad v súčasnom dianí doma a vo svete je nevyhnutne potrebný pre život, majú lepšie vedomosti o svete ako respondenti, ktorí to nepovažujú za až také dôležité.

$\mathrm{V}$ rámci výskumu nás tiež zaujímalo, či dosiahnuté vzdelanie respondentov, ich jazykové schopnosti, frekvencia cestovania a vyhl'adávania informácií spojených s dianím doma a vo svete ovplyvňujú úroveň geografickej gramotnosti. Statistická analýza ukázala, že neexistuje štatisticky významný rozdiel v úrovni geografickej gramotnosti vzhl'adom na dosiahnuté vzdelanie $(3,96 ; \mathrm{p}>0,05)$. Vplyv dosiahnutého vzdelania sa nepreukázal ani $\mathrm{v}$ úrovni vedomostí respondentov $\mathrm{z}$ geografie $(8,28 ; \mathrm{p}>0,05)$. Štatisticky významný rozdiel sa potvrdil v úrovni mapových zručností $(20,56 ; p<0,05)$. Následný post hoc test potvrdil, že respondenti s vysokoškolským vzdelaním I. stupňa riešili úlohy zamerané na mapové zručnosti štatisticky významne lepšie ako respondenti so stredným odborným vzdelaním s maturitou.

Pokial' ide o počet jazykov, ktoré respondenti plynulo ovládajú (okrem českého jazyka), zistili sme, že medzi skupinami existujú štatisticky významné rozdiely $(8,21 ; p<0,05)$ a respondenti, ktorí neovládali ani jeden cudzí jazyk majú štatisticky významne nižšiu úroveň geografickej gramotnosti ako respondenti, ktorí ovládajú jeden cudzí jazyk. Štatisticky významné rozdiely sa preukázali len v mapových 
zručnostiach $(8,10 ; p<0,05)$, kde rovnako respondenti, ktorí neovládali ani jeden cudzí jazyk, majú štatisticky významne horšie mapové zručnosti ako respondenti, ktorí ovládajú jeden cudzí jazyk.

Ako preukázala štatistická analýza, na úroveň geografickej gramotnosti má vplyv aj frekvencia cestovania do zahraničia $(12,69 ; \mathrm{p}<0,05)$. Respondenti, ktorí do zahraničia vycestovali za posledné tri roky tri- a viackrát, mali štatisticky významne vyššiu úroveň geografickej gramotnosti ako respondenti, ktorí v zahraničí za posledné tri roky vôbec neboli. Štatisticky významné rozdiely sa prejavili $\mathrm{v}$ oboch oblastiach, teda aj vo vedomostiach o svete $(8,94 ; \mathrm{p}<0,05)$ aj $\mathrm{v}$ mapových zručnostiach $(13,69 ; \mathrm{p}<0,05)$.

Posledným skúmaným faktorom bola frekvencia vyhl'adávania informácií spojených s dianím doma a vo svete. Štatistická analýza prostredníctvom KruskalWallisovho testu ukázala, že existujú štatisticky významné rozdiely v úrovni geografickej gramotnosti vzhl'adom na frekvenciu vyhl'adávania informácií $(37,43$; $\mathrm{p}<0,05)$. Statisticky významne vyššia úroveň geografickej gramotnosti sa ukázala u respondentov, ktorí pravidelne vyhl'adávajú tieto informácie (3 až 6 ráz týždenne), ako u respondentov, ktorí sa o ne vôbec nezaujímajú alebo len sporadicky, podl'a potreby. Štatisticky významné rozdiely sa potvrdili vo vedomostiach o svete $(44,67 ; \mathrm{p}<0,05)$ aj v mapových zručnostiach $(24,92 ; \mathrm{p}<0,05)$.

V nasledujúcich častiach uvedieme podrobnejšie výsledky a výskumné zistenia týkajúce sa úrovne geografickej gramotnosti mladých l’udí na Slovensku.

\section{Sekcia vedomostí o svete}

Sekciu vedomostí o svete tvorilo celkovo 16 otázok. Priemerná úspešnost' riešenia všetkých otázok nachádzajúcich sa v sekcii vedomostí o svete bola $62,3 \%$, zatial' čo sekcia mapových zručností dosiahla priemernú úspešnost' riešenia otázok 75,7\%.

Najvyššiu úspešnost' riešenia $(278 ; 92,7$ \%) mala otázka týkajúca sa názvu organizácie, ktorá prijala euro ako spoločnú menu. Druhou najmenej problematickou otázkou, ktorej úspešnost' riešenia presiahla $90 \%(272 ; 90,7 \%)$, bola otázka: „Ktorý z nasledujúcich regiónov má najvyššie percento populácie nakazenej vírusom HIV, ktorý spôsobuje ochorenie AIDS?" Na druhej strane, najviac problémov mali slovenskí respondenti s identifikáciou štátov, v ktorých vznikli radikálne islamské organizácie. Na túto otázku poznalo správnu odpoved’ iba 109 (36,3\%) respondentov. Stodvadsat'tri $(41,0 \%)$ respondentov uviedlo, že tieto organizácie vznikli v Iraku a 45 (15,0 \%) označilo za správnu odpoved' Pakistan. Dôvodom nízkej úspešnosti riešenia tejto úlohy môže byt' skutočnost', že mladí l'udia sa o udalostiach, ktoré sa ich bytostne nedotýkajú, dôkladnejšie nezaujímajú. A aj ked' sa informácie spojené s Talibanom a najmä s Al-Káidou v médiách často vyskytovali, prijímali ich pasívne a nevyvíjali úsilie dozvediet' sa o teroristických organizáciách viac faktov.

Druhou otázkou s najnižšou úspešnost'ou riešenia $(39,7 \%)$ bola otázka: „Existuje pravidelne sa opakujúca odchýlka v systéme morského prúdenia, ktorá spôsobuje zmeny teploty oceánov a zároveň zmeny počasia na celom svete. Ako sa tento fenomén nazýva?“ Pri tejto otázke si až 125 (41,7\%) respondentov vybralo za správnu odpoved' Golfský prúd a $38(12,7 \%)$ respondentov si myslelo, že reč je o globálnom otepl'ovaní. Príčinou neznalosti fenoménu El Niño môže byt' fakt, že 
školská geografia mu nevenuje dostatočnú pozornost’ a vo väčšine prípadov ho učitelia na vyučovacích hodinách geografie spomínajú iba vel'mi okrajovo. Omnoho väčšia pozornost' je venovaná Golfskému prúdu, čo zároveň vysvetl'uje, prečo si viac ako $41,0 \%$ respondentov zvolilo za správnu odpoved' práve tento morský prúd.

Prekvapivo problematické a náročné boli pre slovenských respondentov otázky zist'ujúce počet obyvatel'ov Slovenska, Spojených štátov amerických a Európskej únie. Priemerná úspešnost' riešenia týchto troch otázok predstavovala iba $52 \%$. Aj napriek skutočnosti, že Slovensko je už viac ako 15 rokov súčast'ou EÚ, najväčšie problémy robilo respondentom určit' správny počet obyvatel'ov tohto zoskupenia európskych štátov. Správnu odpoved' na túto otázku vedelo iba $130(43,3 \%)$ respondentov. Osemdesiat respondentov (26,7 \%) uviedlo, že Európska únia má 700 750 miliónov obyvatel'ov a $56(18,7 \%)$ respondentov označilo za správnu odpoved' rozmedzie 250 - 300 miliónov obyvatel'ov.

Iba o niečo vyššiu úspešnost' mala otázka zist'ujúca počet obyvatel'ov Spojených štátov amerických, kde správnu odpoved' poznalo iba 177 (48 \%) respondentov. Až $115(38,3 \%)$ respondentov označilo ako správnu odpoved' pri tejto otázke rozmedzie 500 - 750 miliónov obyvatel'ov.

Najlepšie obstáli respondenti pri určovaní počtu obyvatel'ov Slovenska. Úspešnost' riešenia tejto otázky dosiahla 64,7 \%. Avšak 96 respondentov, čiže takmer jedna tretina, správnu odpoved' neuviedla. Ak zoberieme do úvahy, že otázka sa týkala krajiny, v ktorej respondenti žijú a aktívne pôsobia, dosiahnuté percento úspešnosti svedčí o nedostatočných vedomostiach o slovenských reáliách. Šest'desiat respondentov (20,0 \%) si myslelo, že Slovensko má 4,6 - 5 miliónov obyvatel'ov a 40 (13,3\%) označilo za správnu odpoved' interval 5,6 - 6 miliónov obyvatel'ov.

Ďalšie prekvapivé zistenie v tejto vedomostnej sekcii priniesla analýza odpovedí na otázku: „Ktoré štáty majú viac ako jednu miliardu obyvatel’ov?“ Z ponúkaného zoznamu štátov dokázalo vybrat' správnu odpoved' iba $169(56,3 \%)$ respondentov. Až $72(24,0 \%)$ respondentov označilo Rusko ako štát s miliardou obyvatel'ov a $60(20,0 \%)$ respondentov sa rozhodlo zvolit' za správnu odpoved' Spojené štáty americké.

Na otázku, ktoré more obmýva pobrežie mesta Dubrovník, na ktorom sa natáčali scény v jednom z najobl'úbenejších seriálov všetkých čias - Hra o tróny, odpovedalo správne $253(84,3 \%)$ respondentov.

Prekvapivým a neočakávaným zistením bola nižšia úspešnost' odpovedí respondentov na otázku: „Ku ktorým z nasledujúcich environmentálnych problémov môže viest' neustále zvyšovanie emisií oxidu uhličitého?" Na túto otázku odpovedalo správne iba 137 (45,7\%) respondentov.

Pomerne vel'ký problém robila respondentom aj otázka zist'ujúca, medzi ktorými dvoma krajinami prebieha dlhotrvajúci konflikt o región Kašmír. Na túto otázku odpovedalo správne menej ako polovica všetkých zúčastnených respondentov (161; 48,3 \%). Šest'desiatosem $(22,7 \%)$ respondentov sa domnievalo, že konflikt o región Kašmír prebieha medzi krajinami Irak a Irán a 34 (11,3 \%) označilo ako správnu odpoved' krajiny Izrael a Egypt. Úspešnost' otázok v sekcii vedomostí o svete zobrazuje tabul'ka 4. 
Tab. 4. Úspešnost’ odpovedí na otázky zaradené do sekcie vedomostí o svete

\begin{tabular}{|c|c|c|}
\hline Otázky: & $\begin{array}{l}\text { Početnost' } \\
\text { správnych } \\
\text { odpovedí }\end{array}$ & $\begin{array}{l}\text { Úspešnost' } \\
\quad \mathrm{V} \%\end{array}$ \\
\hline $\begin{array}{l}\text { 7. V ktorom z nasledujúcich rozpätí je správne uvedený počet obyvatel'ov } \\
\text { Spojených štátov amerických? }\end{array}$ & 144 & 48,00 \\
\hline $\begin{array}{l}\text { 8. V ktorom z nasledujúcich rozpätí je správne uvedený počet obyvatel’ov } \\
\text { Slovenska? }\end{array}$ & 194 & 64,67 \\
\hline $\begin{array}{l}\text { 9. V ktorom z nasledujúcich rozpätí je správne uvedený počet obyvatel'ov } \\
\text { Európskej únie? }\end{array}$ & 130 & 43,33 \\
\hline 10. Najviac rozšíreným náboženstvom na svete je: & 240 & 80,00 \\
\hline $\begin{array}{l}\text { 11. Z ktorej krajiny pochádza väčšina imigrantov, ktorí prichádzajú do Európy? } \\
\text { (názov krajiny napište, prosím, s diakritikou v základnom tvare) }\end{array}$ & 166 & 55,33 \\
\hline 12. V ktorom štáte vznikli radikálne islamské organizácie Taliban a Al-Káida? & 109 & 36,33 \\
\hline 13. Ktorá z nasledujúcich organizácií prijala euro ako spoločnú menu? & 278 & 92,67 \\
\hline $\begin{array}{l}\text { 14. Mnohé scény v jednom z najobl'úbenejších seriálov všetkých čias, Game } \\
\text { of Thrones, sa natáčali v Dubrovníku. Ktoré more obmýva pobrežie tohto mesta? }\end{array}$ & 253 & 84,33 \\
\hline $\begin{array}{l}\text { 15. Ktorá z nasledujúcich krajín nepatrí medzi najväčších producentov ropy } \\
\text { na svete? }\end{array}$ & 222 & 74,00 \\
\hline $\begin{array}{l}\text { 16. Medzi ktorými dvoma krajinami prebieha dlhotrvajúci konflikt o región } \\
\text { Kašmír? }\end{array}$ & 145 & 48,33 \\
\hline $\begin{array}{l}\text { 17. Existuje pravidelne sa opakujúca odchýlka v systéme morského prúdenia, ktorá } \\
\text { spôsobuje zmeny teploty oceánov a zároveň zmeny počasia na celom svete. Ako sa } \\
\text { tento fenomén nazýva? }\end{array}$ & 119 & 39,67 \\
\hline $\begin{array}{l}\text { 18. Ktorý z nasledujúcich regiónov má najvyššie percento populácie nakazenej víru- } \\
\text { som HIV, ktorý spôsobuje ochorenie AIDS? }\end{array}$ & 272 & 90,67 \\
\hline $\begin{array}{l}\text { 19. Ktorý z nasledujúcich štátov je jediným komunistickým štátom rozprestierajúcim } \\
\text { sa na západnej pologuli? }\end{array}$ & 260 & 86,67 \\
\hline $\begin{array}{l}\text { 20. Ku ktorým z nasledujúcich environmentálnym problémov môže viest' neustále } \\
\text { zvyšovanie emisií oxidu uhličitého? (otázka má viacero správnych odpovedí) }\end{array}$ & 137 & 45,67 \\
\hline $\begin{array}{l}\text { 21. Ktorá z nasledujúcich etnických skupín je najväčšou nearabskou menšinou } \\
\text { v Indii? }\end{array}$ & 151 & 50,33 \\
\hline 22. Ktoré štáty majú viac ako jednu miliardu obyvatel'ov? & 169 & 56,33 \\
\hline
\end{tabular}

\section{Sekcia mapových zručností}

Druhú čast’ testu venovanú mapovým zručnostiam, tvorilo celkom 32 otázok. Túto sekciu zvládli respondenti v priemere lepšie ako sekciu vedomostí o svete. Priemerná úspešnost' odpovedí bola 75,7 \%.

Respondenti vel'mi dobre zvládli otázky týkajúce sa navigácie a orientácie na mape. Najzápadnejšie španielske mesto vedelo na mape správne určit’ až 282 (94,0 \%) respondentov a $268(89,3$ \%) dokázali správne určit' smer cesty z Madridu do Barcelony.

Nadpriemerné schopnosti preukázali respondenti aj pri dvojici otázok týkajúcich sa čítania obsahu mapy. Krajinu s najvyššou hustotou zaludnenia správne identifikovalo až $274(91,3 \%)$ respondentov a na otázku zaoberajúcu sa vrstevnicami odpovedalo správne až $262(87,3 \%)$ respondentov. Dvadsat'osem respondentov $(9,3 \%)$ si zvolilo za správnu odpoved' možnost' s najvyššie položenou vrstevnicou. Výsledky tejto otázky, jej zadanie a použitý mapový výrez zobrazuje tabul'ka 5. 
Tab. 5. Frekvencia odpovedí na otázku určenia najvy̌šsej nadmorskej výšky bodu v obsahu mapy.

\begin{tabular}{ll}
\hline Otázka: & $\begin{array}{l}\text { Početnost' } \\
\text { odpovedí } \%\end{array}$ \\
\hline
\end{tabular}

26. Ktorý z nasledujúcich bodov má najvyššiu nadmorskú výšku?

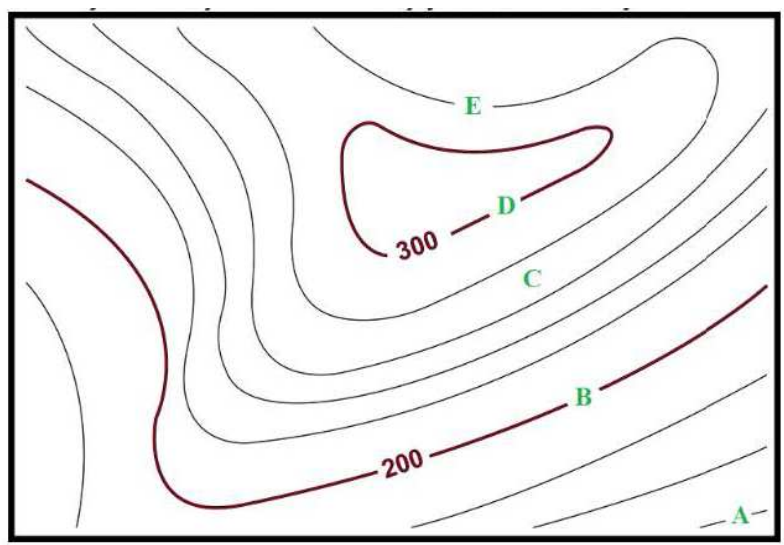

mapa C (vrstevnice)

(v pripade potreby si môžete mapu kliknutím zväčšit)

$\mathrm{a} /$ bod A

$\mathrm{b} /$ bod B

$\mathrm{c} /$ bod C

$\mathrm{d} / \operatorname{bod} \mathrm{D}$

e/ bod E

\begin{tabular}{rr}
1 & $0,33 \%$ \\
1 & $0,33 \%$ \\
3 & $1,00 \%$ \\
262 & $87,33 \%$ \\
28 & $9,33 \%$ \\
5 & $1,67 \%$ \\
\hline
\end{tabular}

Ďalšie otázky v sekcii mapových zručností skúmali schopnost’ respondentov správne určit’ polohu vybraných štátov, oceánov a slovenských miest. Prvú skupinu otázok tvorilo 15 položiek zameraných na správne určenie polohy štátov na mape sveta. V tejto podkategórii mali respondenti za úlohu určit' polohu 13 štátov a dvoch plošne najväčších oceánov. Najmenej problémov mali respondenti s určením správnej lokalizácie európskych krajín, kde úspešnost' riešenia zadaní predstavovala $90,0 \%$ a viac - Spojené král'ovstvo Vel'kej Británie a Severného Írska 93,7 \%, Rusko 93,0 \%, Francúzsko 92,0 \% a Nemecko 90,0 \%. Najmenej úspešní boli respondenti pri určovaní polohy Nigérie a Pakistanu. Správnu polohu Pakistanu určilo na mape iba 117 (39,0 \%) respondentov, pričom Nigériu iba 78 (26,0 \%) respondentov, čo predstavuje najnižšie dosiahnuté percento úspešnosti spomedzi všetkých otázok vôbec. Jedným z faktorov, ktorý môže vplývat' na neznalost' polohy týchto dvoch krajín, je samotný vzdelávací obsah školskej geografie, ktorý sa $\mathrm{z}$ časových dôvodov venuje najmä charakteristike svetadielov ako celku a následne vybraným regiónom.

Pomerne prekvapivé boli zistenia nižšej úspešnosti otázky súvisiacej s lokalizáciou Spojených štátov amerických. Iba 230 (76,7 \%) respondentov dokázalo správne lokalizovat' umiestnenie USA v podkladovej obrysovej mape sveta. Pät'desiat- 
osem respondentov si na mape zamenilo Spojené štáty americké s Kanadou. Pri určovaní polohy dvoch najväčších oceánov - Tichého a Atlantického - preukázali respondenti $\mathrm{v}$ porovnaní $\mathrm{s}$ ostatnými štátmi nadpriemerné výsledky. Tichý oceán dokázalo na mape správne identifikovat' $244(81,3 \%)$ respondentov a Atlantický oceán až $254(84,7 \%$ ). V tabul'ke 6 uvádzame percentuálnu úspešnost' odpovedí respondentov pri určovaní polohy krajín, ktoré neboli zahrnuté v našej analýze.

Tab. 6. Vyhodnotenie správnych odpovedí respondentov pri lokalizácii vybraných štátov sveta

\begin{tabular}{lcc}
\hline Názov krajiny & $\begin{array}{c}\text { Početnost' správnych } \\
\text { odpovedí }\end{array}$ & $\%$ \\
\hline Mexiko & 249 & $83,0 \%$ \\
Argentína & 189 & $63,0 \%$ \\
India & 242 & $81,0 \%$ \\
Japonsko & 260 & $87,0 \%$ \\
Kórejská l'udovodemokratická republika & 216 & $72,0 \%$ \\
Egypt & 196 & $65,0 \%$ \\
\hline
\end{tabular}

Druhá skupina otázok zameraných na určovanie polohy vybraných štátov a miest vychádzala $\mathrm{z}$ obrysovej mapy Blízkeho východu. V jej obsahu mali respondenti správne určit' pät štátov rozprestierajúcich sa na tomto území - Saudskú Arábiu, Izrael, Afganistan, Irak a Irán. Schopnost' respondentov správne určit’ polohu štátov ležiacich v tejto oblasti sveta bola vel'mi obmedzená a spomedzi všetkých otázok zahrnutých do oboch sekcií dosiahli tieto otázky najnižšiu úspešnost' riešenia. Úspešnost' riešenia týchto otázok bola len 45,2 \%. Najmenší problém robilo respondentom správne určit' na mape polohu Saudskej Arábie $(223 ; 74,3 \%)$. Za ňou nasledoval Izrael, ktorý dokázala v podkladovej mape identifikovat' presná polovica respondentov. Ostatné štáty však vedela správne lokalizovat’ iba približne jedna tretina respondentov. Afganistan určilo správne iba 109 (36,3 \%) respondentov, Irán $103(34,3$ \%) a Irak iba $94(31,3 \%)$ respondentov. Dôkladnejšia analýza odpovedí ukázala, že práve pri týchto otázkach využilo najväčšie množstvo respondentov alternatívu odpovede „neviem“. Pri Iraku to bolo až 99 respondentov, čiže $33,0 \%$.

Tretia, posledná čast' otázok, bola zameraná na vedomosti o umiestnení slovenských miest (krajských sídel) na obrysovej mape Slovenska. Percentuálna úspešnost' odpovedí respondentov presiahla pri každom meste 80,0 \%. Hlavné mesto SR vedelo správne určit' v mape až 295 (98,3 \%), Banskú Bystricu 293 (97,7 \%) a Trnavu $270(90,0 \%)$ mladých Slovákov. Ostatné mestá mali úspešnost'odpovedí pod $90 \%$ - Žilina 89,0 \% a Nitra spolu s Prešovom zhodne po 84,0 \%. Najmenej úspešní boli respondenti pri určovaní polohy Trenčína $(251 ; 83,7 \%)$ a Košíc $(242$; 80,7 \%). Pri podrobnejšej analýze odpovedí sme zistili, že respondenti si zamieňali Košice s Prešovom, Nitru s Trnavou a Trenčín so Žilinou. Mapa Slovenska použitá pri týchto otázkach je znázornená na obrázku 7.

V rámci výskumu nás zaujímalo, či existuje vzt’ah medzi vedomost'ami respondentov o svete a ich mapovými zručnost’ami. Spearmanov korelačný koeficient ukázal, že medzi vedomost’ami o svete a mapovými zručnost’ami existuje štatisticky významný vzt’ah. Mieru závislosti môžeme považovat' za stredne silnú $(0,60$; $\mathrm{p}<0,05)$. 


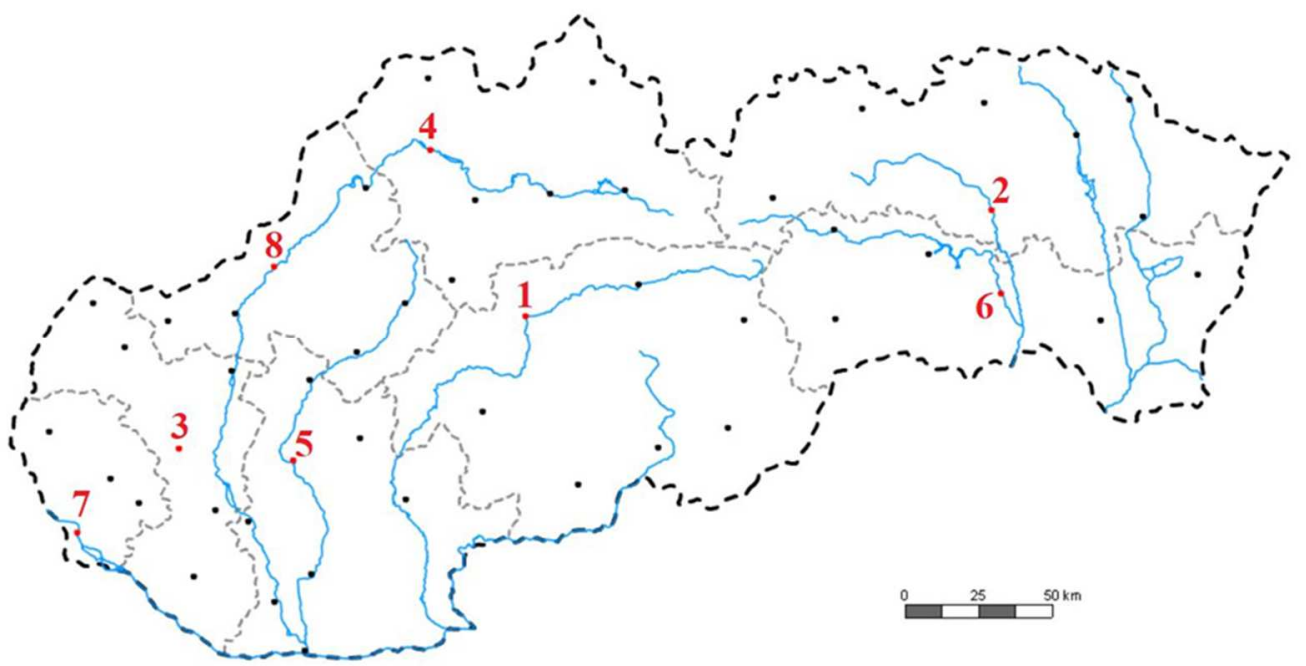

Obr. 7. Obrysová mapa Slovenska použitá pri otázkach zameraných na určenie polohy vybraných slovenských miest

\section{ZÁVER}

Ciel’om výskumu bolo zistit' dosiahnutú úroveň geografickej gramotnosti mladých l'udí vo veku 18 až 24 rokov na Slovensku. Výsledky výskumu preukázali všeobecne vel'mi dobrú úroveň geografickej gramotnosti. Respondenti získali v priemere 34,2 bodov (zo 48), čo predstavuje 71,2 \%. Dosiahnuté bodové skóre viac ako polovice respondentov (159 respondentov, 53,0 \%) bolo vyššie ako hodnota výsledného priemerného skóre všetkých respondentov. Na druhej strane odpovedalo $35(11,7 \%)$ respondentov správne iba na menej ako polovicu otázok a 5 $(1,7 \%)$ respondentov nevedelo správne odpovedat' ani na jednu tretinu otázok. Celkovo však možno považovat' dosiahnutú úroveň geografickej gramotnosti zúčastnených na výskume za vel'mi dobrú.

Najväčšie problémy robili respondentom otázky s úspešnost'ou riešenia pod 40,0\%. V sekcii vedomostí o svete išlo o otázky identifikácie štátov, v ktorých vznikli radikálne islamské organizácie (úspešnost' 36,3 \%) a vplyvu fenoménu El Niño $(39,7 \%)$. V sekcii mapových zručností to boli otázky spojené so správnym určením polohy Nigérie (26,0 \%), Pakistanu $(39,0 \%)$ a krajín Blízkeho východu Iraku 31,3\%, Iránu 34,3\% a Afganistanu 36,3\%.

Naopak, medzi najmenej obtažné otázky v sekcii vedomostí o svete sa zaradili otázky o organizácii, ktorá prijala euro ako spoločnú menu (úspešnost' 92,7 \%) a regióne s najvyšším percentom populácie nakazenej vírusom HIV (90,7 \%). Najmenej problémov v sekcii mapových zručností mali respondenti s otázkami týkajúcimi sa určovania najzápadnejšieho mesta Španielska (94,0 \%), afrického štátu s najvyššou hustotou zal'udnenia $(91,3 \%$ ), polohy európskych krajín (Spojené král'ovstvo Vel'kej Británie a Severného Írska 93,7 \%, Rusko 93,0 \%, Francúzsko $92,0 \%$ a Nemecko 90,0 \%) a niektorých slovenských miest (Bratislava 98,3\%, Banská Bystrica 97,7 \% a Trnava 90,0 \%). 
Detailnejšiemu porovnaniu výsledkov výskumu realizovaného na súbore mladých Slovákov s medzinárodným výskumom organizovaným National Geographic bránia použité výskumné nástroje, ktoré síce boli podobné (prebratých bolo viac ako dve tretiny úloh), no nie identické. Výber respondentov navyše nepredstavoval reprezentatívny súbor zo skupiny 18- až 24-ročných Slovákov. Ak by sme tieto fakty nebrali do úvahy a porovnali medzi sebou výsledky slovenských a švédskych respondentov, ktorí dosiahli vo výskume National Geographic najvyššie skóre (National Geographic Society 2020), zistili by sme, že úroveň geografickej gramotnosti slovenských respondentov je na rovnakej úrovni ako geografická gramotnost' ich rovesníkov zo Švédska.

Ak porovnáme výsledky nášho výskumu s výsledkami výskumu realizovaného spoločnost'ou National Geographic (National Geographic Society 2020), zistíme, že schopnost' správne určit' štáty Blízkeho východu na podkladovej mape robilo problém všetkým účastníkom medzinárodného výskumu. Vo výskume National Geographic sa na prvom mieste umiestnili respondenti zo Švédska, z ktorých iba 30,0 \% vedelo nájst' na mape Irak. Polohu Iránu správne určilo 33,0 \% respondentov, Izraelu 41,0 \% a Afganistanu iba 26,0 \% respondentov. Úspešnost' správneho určenia polohy Slovákmi bola pri Iraku 31,3\%, Iráne 34,3\% a Afganistane $36,3 \%$.

V rámci výskumu nás zaujímalo, či existujú štatisticky významné vzt'ahy medzi sledovanými názormi a postojmi respondentov a dosiahnutou úrovňou geografickej gramotnosti. Naše zistenia čiastočne kopírujú výsledky výskumov realizovaných spoločnost'ou National Geographic (Roper 2002). Rovnako, ako to bolo pri medzinárodnom výskume uskutočnenom v roku 2002 - aj naše zistenia potvrdili, že respondenti, ktorí neovládali ani jeden cudzí jazyk majú štatisticky významne nižšiu úroveň geografickej gramotnosti ako respondenti, ktorí ovládajú minimálne jeden cudzí jazyk. Podobnost' výsledkov sme identifikovali aj pri frekvencii vycestovania. Respondenti, ktorí do zahraničia vycestovali za posledné tri roky tri- a viackrát mali štatisticky významne vyššiu úroveň geografickej gramotnosti ako respondenti, ktorí v zahraničí za posledné tri roky neboli vôbec. Statistická analýza tiež potvrdila, že respondenti, ktorí uviedli, že prehl'ad v súčasnom dianí doma a vo svete je nevyhnutne potrebný pre život, majú lepšie vedomosti o svete ako respondenti, ktorí to nepovažujú až za také dôležité. Vyššia úroveň geografickej gramotnosti sa tiež ukázala u respondentov, ktorí pravidelne vyhl'adávajú informácie o dianí doma i vo svete, oproti tým, ktorí sa o ne nezaujímajú vôbec alebo len sporadicky podl'a potreby.

Treba si však uvedomit', že hodnotenie úrovne geografickej gramotnosti je mimoriadne náročný a zložitý proces. Hl'adanie odpovedí na otázku, akými vedomost’ami, schopnost’ami či zručnost’ami disponuje geograficky gramotný jedinec naráža, v praxi na viacero koncepčných problémov. Medzi také určite patrí stanovenie základného rámca faktografických a encyklopedických poznatkov nevyhnutných pri riešení geografických problémov. Problematickým sa tiež javí spôsob vhodného overovania schopností jedinca správne identifikovat' vzt'ahy a väzby medzi pozorovanými prvkami, porozumiet' súvislostiam i príčinám, odhadovat' vývoj či dôsledky významných svetových udalostí. Uvedomujeme si, že použitý a z vel'kej časti prebraný výskumný nástroj má svoje obmedzenia a je schopný rozpoznat' iba čast' spôsobilostí reprezentujúcich geografickú gramotnost'. 


\section{REFERENCES}

APPEL, S. (2020). Geospatial information literacy instruction: Frameworks, competency, and threshold concepts. Journal of Map \& Geography Libraries, 15, 134-151. DOI: https://doi.org/10.1080/15420353.2020.1760175.

BEIN, F. (1990). Baseline geography competency test: Administered in Indiana universities. Journal of Geography, 89, 260-265. DOI: https://doi.org/10.1080/0022134900 8979213.

BEDNARZ, S. W., KEMP, K. (2011). Understanding and nurturing spatial literacy. Procedia Social and Behavioral Sciences, 21, 18-23. DOI:10.1016/j.sbspro.2011.07.004.

BOARD, C. (1978). Map reading tasks appropriate in experimental studies in cartographic communication. Cartographica: The International Journal for Geographic Information and Geovisualization, 15, 1-12.

CLARKE, D. (2003). Are you functionally map literate? Cartographic Renaissance, Proceedings of 21st International Cartographic Conference (ICC), Durban, South Africa: International Cartographic Association (ICA), pp. 713-719, [Online]. Available: http:// lazarus.elte.hu/cet/publications/088.pdf [accessed 12 August 2018].

COSGROVE, D. (2004). Landscape and landschaft. German Historical Institute Bulletin, $35,57-71$.

EDELSON, D. C. (2012). Geo-Education: Preparation for 21st-century decisions, [Online]. Available: https://www.nationalgeographic.org/article/geo-educationpreparation-21st-century-decisions/?utm source=BibblioRCM Row [accessed 4 December 2016].

EDELSON, D. C. (2014). Geo-Literacy, [Online]. Available: https://www. nationalgeographic.org/news/geo-literacy-preparation-far-reaching-decisions/ [accessed 11 January 2018].

EVE, R., PRICE, B., COUNTS, M. (1994). Geographic illiteracy among college students. Youth and Society, 25, 408-427.

FUJITA, M., KRUGMAN, P., VENABLES, A. J. (2001). The spatial economy: Cities, regions, and international trade. Boston (MIT Press).

GAVORA, P. (2006). C'́tanie, pisanie a gramotnost' - ich premeny v súčasnom svete, [Online]. Available: https://www.unipo.sk/public/media/11314/Slovo\%20o\%20slove\% 2012\%20-\%202006.pdf\#page $=24$ [accessed 24 July 2019].

GOODCHILD, MF (2006). GIScience Ten Years After Ground Truth. Transactions in GIS, 10, 687-692. DOI: https://doi.org/10.1111/j.1467-9671.2006.01022.x.

GOODCHILD, M. F., JANELLE, D. G. (2010). Toward critical spatial thinking in the social sciences and humanities. GeoJournal, 75, 3-13.

LAURIER, E., BROWN, B. (2008). Rotating maps and readers: Praxiological aspects of alignment and orientation. Transactions of the Institute of British Geographers, 33, 201221.

MACONOCHIE, A. (1988). Geography: An international Gallup survey, [Online]. Available: http://mje.mcgill.ca/article/download/7887/5816 [accessed 4 November 2019].

NATIONAL GEOGRAPHIC SOCIETY (2020). What is Geo-literacy? [Online]. Available: https://www.nationalgeographic.org/media/what-is-geo-literacy/\#: :text=Geo\% 2Dliteracy $\% 20$ is $\% 20$ the $\% 20$ term,to $\% 20$ make $\% 20$ far $\% 2$ Dreaching $\% 20$ decisions. [accessed 25 September 2020].

NATIONAL RESEARCH COUNCIL (2006). Learning to think spatially. Washington, DC (The National Academies Press). DOI: https://doi.org/10.17226/11019.

MORRISON, J. L. (1978), Towards a functional definition of the science of cartography with emphasis on map reading. The American Cartographer, 5, 97-110.

OLSON, J. M. (1976). A coordinated approach to map communication improvement. The American Cartographer, 3, 151-159.

PARKER, M. (2009). Map addict: A tale of obsession, fudge and the ordnance survey. London (Collins). 
PATEL, J., BALL, D. J., JONES, H. (2008). Factors influencing subjective ranking of driver distractions. Accident Analysis and Prevention, 40, 392-395.

PRAVDA, J. (2001). Kartografická gramotnost', čítanie máp a generovanie poznatkov z máp. Geodetický a kartografický obzor, 9, 212-216.

PRAVDA, J. (2003). Mapový jazyk. Bratislava (Univerzita Komenského).

PRŮCHA, J. (2009). Pedagogická encyklopedie. Praha (Portál).

PRÜCHA, J., WALTEROVA, E., MARES, J. (2001). Pedagogický slovník. Praha (Portál).

ROPER (2002). National Geographic - Roper 2002 Global Geographic Literacy Survey, [Online]. Available: https://www.thestudentroom.co.uk/attachment.php? attachmentid $=301605 \& \mathrm{~d}=1405465338$ [accessed 25 July 2019].

ROPER (2006). National Geographic - Roper Public Affairs 2006 Geographic Literacy Study, [Online]. Available: https://media.nationalgeographic.org/assets/file/NGS-Roper -2006-Report.pdf [accessed 25 July 2019].

STANSFIELD, CH. (2002). Building geography literacy. New Jersey (Prentice Hall).

SPEAKE, J., AXON, S. (2012). "I Never Use 'Maps' Anymore": Engaging with Sat Nav Technologies and the Implications for Cartographic Literacy and Spatial Awareness. The Cartographic Journal, 49, 326-336. DOI: 10.1179/ 1743277412Y.0000000021.

THE EDVOCATE (2020). [Online]. Available: https://www.theedadvocate.org/ [accessed 15 July 2020].

TORRENS, P. (2002). Where in the world? Exploring the factors driving place location knowledge among secondary level students in Dublin, Ireland. Journal of Geography, 100(2), 49-60. DOI: 10.1080/00221340108978417.

UNITED STATES GOVERNMENT ACCOUNTABILITY OFFICE. (2015). Most eighth grade students are not proficient in geography, [Online]. Available: https:// www.gao.gov/assets/680/673128.pdf [accessed 25 July 2019].

VOŽENILEK, V. (2009). Gramotné čtení map. Vesmír, 88, 10.

WACKERSHAUSEROVÁ, M. (2018). Geografická gramotnost laické veřejnosti. Diplomová práce, Př́rodovědecká fakulta Univerzity Karlovy v Praze, Praha.

WINSHIP, J. (2004). Geographic literacy and World knowledge among undergraduate college students. Diploma thesis, Virginia Polytechnic Institute and State University), Blacksburg.

XIE, M., VACHER, H. L., READER, S., WALTON, E. (2018). Quantitative map literacy: A cross between map literacy and quantitative literacy. Numeracy, 11, 4. DOI: https:// doi.org/ 10.5038/1936-4660.11.1.4.

\section{Štefan Karolčik, Dominika Vavrincová, Elena Č i p ková}

\section{GEO-LITERACY OF YOUNG PEOPLE IN SLOVAKIA}

In this paper, we present the results of our research aimed at determining the achieved level of geographic literacy in young people aged from 18 to 24 in Slovakia. Our research also included analyzes of respondents' attitudes and opinions on geography and their perception of its importance in today's world, as well as findings on the extent of geographical knowledge of young Slovaks related to their ability to orient themselves in current events at home and abroad.

In the research, we used a modified research tool, which was designed by the international research agency Roper ASW at the request of National Geographic and used in the National Geographic research - Roper 2002 Global Geographic Literacy Survey (Roper 2002).

Generally, the research results showed a very good level of geographic literacy. The average number of points of the participating respondents was 34.2, which represents the percentage score of 71.2. The questions with the highest success concerned the location of 
Slovak cities on the map. On the other hand, the lowest success questions concerned Nigeria's location on the world map (26.0\%) and Iraq's location of the map of the Middle East $(31.3 \%)$.

Moreover, the research proved statistically the important relationship between respondents' knowledge about the world and their map skills. At the same time, it was proved that the respondents who do not speak any foreign language reached a statistically significantly lower level of geo-literacy than respondents who speak at least one foreign language. We identified the similarity of the research results realized by the company National Geographic (National Geographic - Roper 2002) also in the frequency of travelling. The respondents who travelled abroad in the last three years three or more times reached a statistically significantly higher level of geo-literacy than the respondents who did not travel abroad at all in the last three years. The statistical analysis also proved that the respondents who stated that the overview in the current affairs at home and abroad is inevitably necessary for their lives have better knowledge of the world than the respondents who do not consider it so important. A higher level of geo-literacy was also symptomatic among respondents who regularly search information about events at home and abroad in comparison to those who are not interested in them at all, or only occasionally. 
